Article

\title{
Naturally-Derived Amphiphilic Polystyrenes Prepared by Aqueous Controlled/Living Cationic Polymerization and Copolymerization of Vinylguaiacol with $\mathrm{R}-\mathrm{OH} / \mathrm{BF}_{3} \cdot \mathrm{OEt}_{2}$
}

\author{
Hisaaki Takeshima, Kotaro Satoh * and Masami Kamigaito *(1) \\ Department of Molecular and Macromolecular Chemistry, Graduate School of Engineering, Nagoya University \\ Furo-cho, Chikusa-ku, Nagoya 464-8603, Japan; takeshima@chiral.apchem.nagoya-u.ac.jp \\ * Correspondence: satoh@chembio.nagoya-u.ac.jp (K.S.); kamigait@chembio.nagoya-u.ac.jp (M.K.); \\ Tel.: +81-52-789-5400 (M.K.)
}

Received: 29 November 2018; Accepted: 15 December 2018; Published: 18 December 2018

\begin{abstract}
In this study, we investigated direct-controlled/living cationic polymerization and copolymerization of 4-vinylguaiacol (4VG), i.e., 4-hydroxy-3-methoxystyrene, which can be derived from naturally-occurring ferulic acid, to develop novel bio-based amphiphilic polystyrenes with phenol functions. The controlled/living cationic polymerization of $4 \mathrm{VG}$ was achieved using the $\mathrm{R}-\mathrm{OH} / \mathrm{BF}_{3} \cdot \mathrm{OEt}_{2}$ initiating system, which is effective for the controlled/living polymerization of petroleum-derived 4-vinylphenol in the presence of a large amount of water via reversible activation of terminal $\mathrm{C}-\mathrm{OH}$ bond catalyzed by $\mathrm{BF}_{3} \cdot \mathrm{OEt}_{2}$, to result in the polymers with controlled molecular weights and narrow molecular weight distributions. The random or block copolymerization of $4 \mathrm{VG}$ was also examined using $p$-methoxystyrene (pMOS) as a comonomer with an aqueous initiating system to tune the amphiphilic nature of the $4 \mathrm{VG}$-derived phenolic polymers. The obtained polymer can be expected not only to be used as a novel styrenic bio-based polymer but also as a material with amphiphilic nature for some applications.
\end{abstract}

Keywords: cationic polymerization; controlled/living polymerization; aqueous media; naturally-occurring monomer; phenolic styrene; amphiphilic polymer

\section{Introduction}

Living or controlled polymerization is one of the most facile methods for preparing various well-defined macromolecular architectures with functional groups, including amphiphilic block copolymers that consist both of hydrophilic and hydrophobic segments [1]. The living cationic polymerization has been conducted using a binary initiating system containing a protonic acid or its adduct of monomer (initiator) and a metal-based Lewis acid (co-initiator or catalyst), which has also been applied for the synthesis of a series of amphiphilic polymers that consist of functional vinyl ether or styrene [2-7]. In cationic polymerization, however, the reaction is generally performed in a rigorously-dried medium. This is because a small amount of water could be an initiator, namely, a so-called "cationogen", when coupled with a strong Lewis acid. In large amounts, water can deactivate the catalyst or growing cation via hydrolysis and often induces chain-transfer reactions to produce only low-molecular-weight polymers. In contrast, approximately 20 years ago, controlled/living cationic polymerization in a water system was realized with $\mathrm{BF}_{3} \cdot \mathrm{OEt}_{2}$ as the Lewis acid, which possibly induced selective activation of a stable carbon-oxygen bond $(\mathrm{R}-\mathrm{OH})$ that was generated by the reaction between the carbocation and water [8-14]. Furthermore, the $\mathrm{R}-\mathrm{OH} / \mathrm{BF}_{3} \cdot \mathrm{OEt}_{2}$ system was applicable even for the direct controlled/living cationic polymerization of $p$-hydroxystyrene $(\mathrm{pHS}$ ) or 4-vinylphenol 
without any protective groups to produce functional hydrophilic polymers that have a phenolic group in the side chain and a controlled molecular weight.

From the viewpoint of sustainable development, in recent years, the use of plant-derived compounds has become important [15-31]. We have also conducted polymerization studies of various naturally-derived vinyl compounds as raw materials for creating novel bio-based polymers [32-49]. One of these has a phenylpropanoid skeleton, which mainly occurs in vegetable oil, such as $\beta$-methylstyrenes and cinnamic acids [50-52]. These compounds are biosynthesized in plant cells, especially for the production of lignin via oxidative coupling or cross-linking [53,54]. We found that $\beta$-methylstyrene of isoeugenol, which is considered to be an amphiphilic monomer that has a phenolic hydroxyl and a hydrophobic methoxy group in the pendant group, did not homopolymerize, but could be copolymerized with $p$-methoxystyrene (pMOS) by the aqueous $\mathrm{R}-\mathrm{OH} / \mathrm{BF}_{3} \cdot \mathrm{OEt}_{2}$ system [44]. Although the copolymerization of isoeugenol produced copolymers that contain naturally-derived phenolic groups, the hydrophilicity could not be changed due to the alternating cross-propagation during the copolymerization with pMOS.

A similar amphiphilic styrene to isoeugenol has been found among natural products, which is 4-hydroxy-3-methoxystyrene [55-58], a naturally-occurring fragrance component called 4-vinylguaiacol (4VG). This compound can also be prepared from the naturally-abundant ferulic acid via decarboxylation $[59,60]$. Recently, we also reported that the controlled radical homopolymerization of protected $4 \mathrm{VG}$ successfully proceeded via reversible addition-fragmentation chain transfer (RAFT) polymerization or nitroxide-mediated polymerization (NMP), where the phenolic functional group had to be protected even for radical polymerization because the phenolic group generally acts as an inhibitor or retarder in radical reactions [47].

In this study, we aimed to develop novel amphiphilic-phenolic bio-based polystyrenes by direct homopolymerization and copolymerization of $4 \mathrm{VG}$ without using any protective groups. In particular, the direct-cationic homopolymerization of $4 \mathrm{VG}$ was examined in an aqueous system using the $\mathrm{R}-\mathrm{OH} / \mathrm{BF}_{3} \cdot \mathrm{OEt}_{2}$ system and copolymerization with pMOS to produce statistical and block copolymers (Scheme 1). The properties of the various types of 4 VG-based polystyrenes obtained were also evaluated for use as naturally-derived amphiphilic polystyrenes. This study thus enables the direct synthesis of novel bio-based amphiphilic polystyrenes with phenolic functions without using tedious protection and deprotection procedures, which will be a great advantage in terms of not only renewable functional materials but also facile synthetic procedures.

1. Living Cation ic Polym erization of $4 V G$

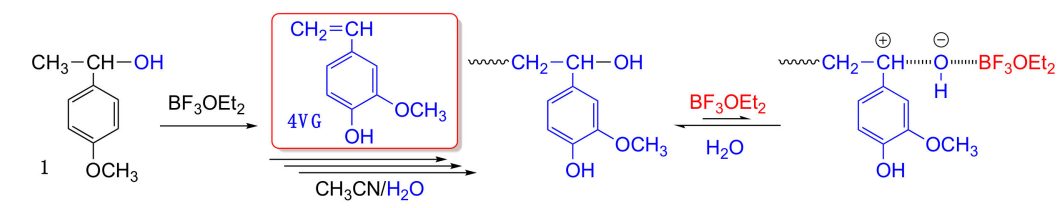

2. Living Cation ic Copolym erization of $4 V G$ w ith $p M O S$

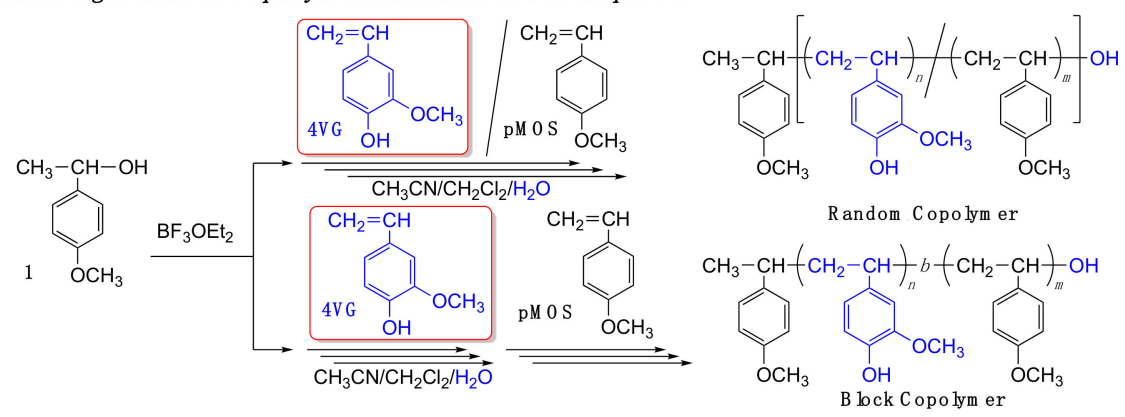

Scheme 1. Synthesis of bio-based amphiphilic polystyrenes from 4-vinylguaiacol (4VG) using aqueous-controlled/living-cationic polymerization and copolymerization. 


\section{Materials and Methods}

\subsection{Materials}

4-Vinylguaiacol (4VG) (Aldrich, St. Louis, MO, USA, >98\%) and $p$-methoxystyrene (pMOS) (4-vinylanisole; Aldrich; 97\%) were distilled under reduced pressure before use. The water adduct of pMOS (1: 4-methoxy- $\alpha$-methylbenzyl alcohol (Aldrich; $99 \%)$ ) was distilled over calcium hydride $\left(2 \mathrm{mmHg}, 110{ }^{\circ} \mathrm{C}\right.$ ) before use. $\mathrm{BF}_{3} \cdot \mathrm{OEt}_{2}$ (Aldrich; purified, redistilled) and acetonitrile $\left(\mathrm{CH}_{3} \mathrm{CN}\right.$ ) (FUJIFILM Wako Pure Chemical Corporation, Osaka, Japan, $\mathrm{H}_{2} \mathrm{O}<50 \mathrm{ppm}$ ) were used as received. Dichloromethane $\left(\mathrm{CH}_{2} \mathrm{Cl}_{2}\right)\left(\mathrm{KANTO}\right.$, Tokyo, Japan, $\left.>99.5 \% ; \mathrm{H}_{2} \mathrm{O}<0.005 \%\right)$ was deoxygenized and dried by passing through a column from Glass Contour Systems (Glass Contour, Nashua, NH, USA) before use. Distilled deionized water was used for the polymerizations without degassing. Acetic anhydride (TCI, Tokyo, Japan, $>99 \%$ ) and pyridine (TCI, >99\%) were used as received.

\subsection{Aqueous Cationic Polymerization of 4-vinylguaiacol (4VG)}

The polymerization of $4 \mathrm{VG}$ was performed by the syringe technique under dry nitrogen in baked glass tubes equipped with a three-way stopcock. A typical example for $4 \mathrm{VG}$ polymerization is given below. The polymerization was initiated by adding solutions of $\mathrm{BF}_{3} \cdot \mathrm{OEt}_{2}\left(20 \mathrm{mM}^{2} \mathrm{CH}_{3} \mathrm{CN}\right.$; $0.50 \mathrm{~mL})$ into a monomer solution $(4.5 \mathrm{~mL})$ that contained $4 \mathrm{VG}(0.14 \mathrm{~mL}, 1.0 \mathrm{mmol})$ and $1(2.8 \mu \mathrm{L}$, $0.02 \mathrm{mmol})$, and water $(0.018 \mathrm{~mL})$ and $o-\mathrm{C}_{6} \mathrm{H}_{4} \mathrm{Cl}_{2}$ as an internal standard $(0.08 \mathrm{~mL})$ in $\mathrm{CH}_{3} \mathrm{CN}(4.27 \mathrm{~mL})$ at $0{ }^{\circ} \mathrm{C}$. The total volume of the reaction mixture was thus $5.0 \mathrm{~mL}$. After a predetermined time, the polymerization was terminated by diluting with methanol $(1.0 \mathrm{~mL})$. Monomer conversion was determined from the concentration of the residual monomers as measured by ${ }^{1} \mathrm{H}$ NMR ( $95 \%$ for $1 \mathrm{~h}$ ). The polymer was isolated via precipitation into a mixture of $n$-hexane and toluene $(1: 1 ; 100 \mathrm{~mL})$. The filtrated precipitate was dissolved in methanol and evaporated until dry under a reduced pressure to produce the polymer product $\left(M_{\mathrm{n}}=12,800, M_{\mathrm{w}} / M_{\mathrm{n}}=1.37\right)$.

\subsection{Block Copolymerization of $4 V G$ and $p M O S$ with the $\mathrm{R}-\mathrm{OH} / \mathrm{BF}_{3} \cdot \mathrm{OEt}_{2}$ System}

The block copolymerization of $4 \mathrm{VG}$ and pMOS was performed via the syringe technique under dry nitrogen in baked glass tubes equipped with a three-way stopcock. A typical example of the block copolymerization is given below. The polymerization of $4 \mathrm{VG}$ was first initiated by adding solutions of $\mathrm{BF}_{3} \cdot \mathrm{OEt}_{2}\left(20 \mathrm{mM}\right.$ in $\left.\mathrm{CH}_{3} \mathrm{CN} ; 0.50 \mathrm{~mL}\right)$ into a monomer solution $(4.5 \mathrm{~mL})$ that contained $4 \mathrm{VG}(0.068 \mathrm{~mL}$, $0.50 \mathrm{mmol}), 1(2.8 \mu \mathrm{L}, 0.02 \mathrm{mmol})$, water $(0.018 \mathrm{~mL})$, and $o-\mathrm{C}_{6} \mathrm{H}_{4} \mathrm{Cl}_{2}$ as an internal standard $(0.07 \mathrm{~mL})$ in the mixture of $\mathrm{CH}_{3} \mathrm{CN}(3.34 \mathrm{~mL})$ and $\mathrm{CH}_{2} \mathrm{Cl}_{2}(1.0 \mathrm{~mL})$ at $0{ }^{\circ} \mathrm{C}$. The total volume of the reaction mixture was $5.0 \mathrm{~mL}$. After $1 \mathrm{~h}$ (the conversion of $\left.4 \mathrm{VG}=88 \%, M_{\mathrm{n}}=7000, M_{\mathrm{w}} / M_{\mathrm{n}}=1.32\right)$, pMOS $(0.067 \mathrm{~mL}$, $0.50 \mathrm{mmol}$ ) was added into the reaction solution. After $40 \mathrm{~h}$, the polymerization was terminated by diluting with methanol $(1.0 \mathrm{~mL})$. The conversions of $4 \mathrm{VG}$ and pMOS were determined from the concentrations of the residual monomers as measured by ${ }^{1} \mathrm{H}$ NMR (4VG: $>99 \%$ and pMOS: $95 \%$ ). The solution was diluted with ethyl acetate $(150 \mathrm{~mL})$, washed with water to remove initiator residues, and evaporated until dry under reduced pressure to give the block copolymer product $\left(M_{\mathrm{n}}=11,100\right.$, $\left.M_{\mathrm{W}} / M_{\mathrm{n}}=1.42,4 \mathrm{VG} / \mathrm{pMOS}=51 / 49\right)$.

\subsection{Measurements}

${ }^{1} \mathrm{H}$ NMR spectra were recorded on a JEOL ECS-400 spectrometer (JEOL, Tokyo, Japan) operated at $400 \mathrm{MHz}$. The number-average molecular weights $\left(M_{\mathrm{n}}\right)$ and molecular weight distributions $\left(M_{\mathrm{w}} / M_{\mathrm{n}}\right)$ of the product polymers were determined via size-exclusion chromatography (SEC) in DMF containing $100 \mathrm{mM} \mathrm{LiCl}$ at $40{ }^{\circ} \mathrm{C}$ on two hydrophilic polymer gel columns [Tosoh $\alpha-\mathrm{M}+\alpha-3000$ (7.8 mm i.d. $\times$ $30 \mathrm{~cm}$ ) (Tosoh Corporation, Tokyo, Japan); flow rate of $1.0 \mathrm{~mL} / \mathrm{min}$ ] (for poly $(4 \mathrm{VG})$ ) connected to a JASCO PU-2080 precision pump and a JASCO RI-2031 detector (JASCO, Tokyo, Japan). The columns were calibrated against standard polystyrene samples (Agilent Technologies, Santa Clara, CA, USA; $\left.M_{\mathrm{p}}=580-3,053,000, M_{\mathrm{w}} / M_{\mathrm{n}}=1.02-1.23\right)$. The glass transition temperature $\left(T_{\mathrm{g}}\right)$ of the polymers was 
recorded on a Q200 differential-scanning calorimeter (TA Instruments, Inc., New Castle, DE, USA), and the $T_{\mathrm{g}}$ values were obtained from the second scan after removing the thermal history. The samples were first heated to $210{ }^{\circ} \mathrm{C}$ at $10^{\circ} \mathrm{C} / \mathrm{min}$, equilibrated at this temperature for $10 \mathrm{~min}$, and cooled to $-60^{\circ} \mathrm{C}$ at $5{ }^{\circ} \mathrm{C} / \mathrm{min}$. After holding at this temperature for $5 \mathrm{~min}$, the samples were then reheated to 210 or $260^{\circ} \mathrm{C}$ at $10^{\circ} \mathrm{C} / \mathrm{min}$. The thermogravimetric analyses (TGA) were performed on a Q500 system (TA Instruments Inc.) at $5{ }^{\circ} \mathrm{C} /$ min under a $\mathrm{N}_{2}$ gas flow.

\section{Results and Discussion}

\subsection{Poly(vinylguaiacol) via Aqueous Cationic Polymerization}

The direct cationic polymerization of the bio-based phenolic monomer, 4VG, was investigated in an aqueous solution of $\mathrm{CH}_{3} \mathrm{CN}$ using an initiating system consisting of the water adduct of pMOS (1) as the initiator and $\mathrm{BF}_{3} \cdot \mathrm{OEt}_{2}$ as the Lewis acid catalyst, which was effective for controlling the polymerization of $\mathrm{pHS}$ as reported in previous literature [8]. The polymerization of $4 \mathrm{VG}$ was performed in $\mathrm{CH}_{3} \mathrm{CN} / \mathrm{H}_{2} \mathrm{O}$ at $0{ }^{\circ} \mathrm{C}$ in which the concentration of water was equal to that of the monomer $\left(\left[\mathrm{H}_{2} \mathrm{O}\right]_{0}\right.$ $\left.=[4 \mathrm{VG}]_{0}=200 \mathrm{mM}\right)$ with large excess of catalyst $\left(\left[\mathrm{BF}_{3} \cdot \mathrm{OEt}_{2}\right]_{0}=2.0 \mathrm{mM}\right)$. As shown in Figure 1, the $4 \mathrm{VG}$ polymerization proceeded smoothly, was of first-order with respect to monomer, and reached complete conversion (95\%) in $1 \mathrm{~h}$, indicating that the catalyst was not decomposed or deactivated by either the added water or phenolic monomer. The polymerization of $4 \mathrm{VG}$ was faster than that of pHS (95\% conversion in $3 \mathrm{~h}$ ) under the same condition, suggesting a higher reactivity of $4 \mathrm{VG}$ due to the two electron-donating substituents on the phenyl group. The SEC curves of the obtained polymer were unimodal and shifted as the polymerization proceeded, maintaining a relatively narrow molecular weight distribution (MWD) $\left(M_{\mathrm{w}} / M_{\mathrm{n}} \sim 1.3\right)$. The $M_{\mathrm{n}}$ increased linearly but was higher than the calculated value, assuming that one polymer chain is formed from one initiator $\mathbf{1}$ molecule, which was likely due to the difference in hydrodynamic volume compared with standard polystyrene. Then, the acetylation of phenolic groups in the obtained polymer was achieved using an excess amount of acetic anhydride at $100{ }^{\circ} \mathrm{C}$ in pyridine [8]. As a result, quantitative acetylation proceeded to result in an $M_{\mathrm{n}}$ for the polymer close to the calculated value at each conversion. A slightly higher $M_{\mathrm{n}}$ at a low monomer conversion was most probably due to the loss of low-molecular weight polymers during recovery of the polymers by precipitation. Thus, the aqueous-controlled/living-cationic polymerization of $4 \mathrm{VG}$ likely proceeded to form one molecule of polymer from one initiator molecule as in the case of the pHS polymerization.
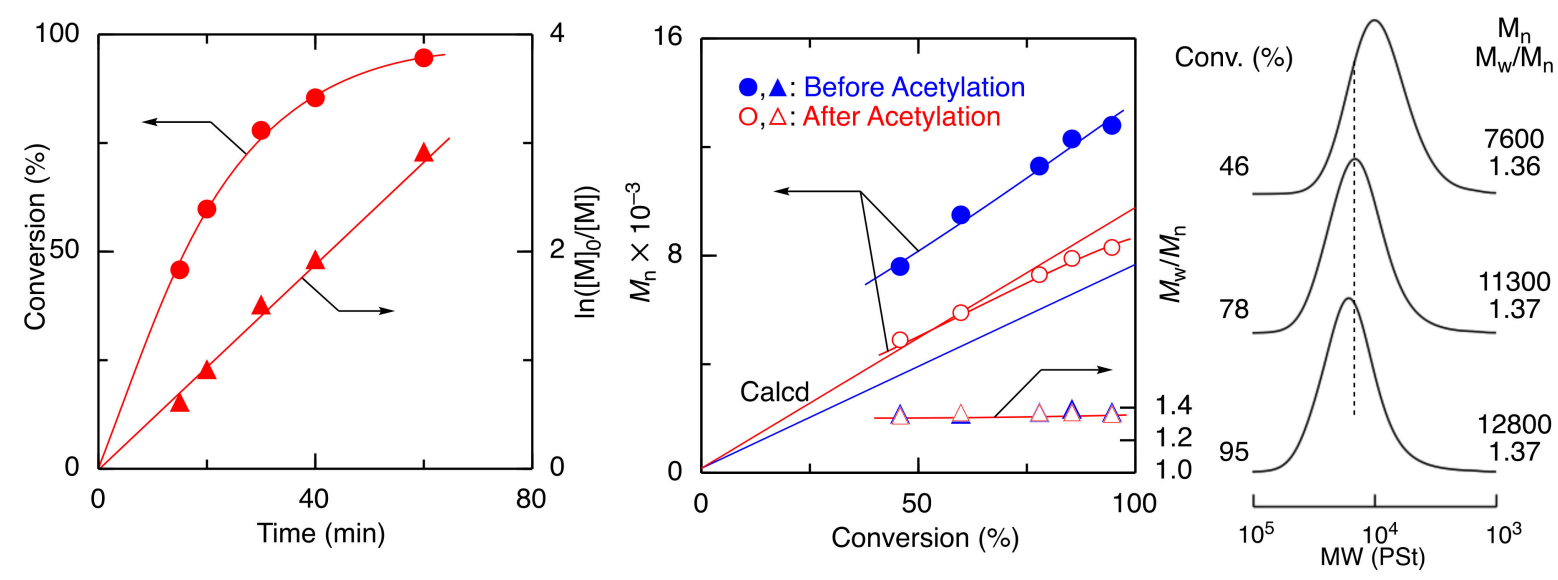

Figure 1. Aqueous-controlled/living-cationic polymerization of $4 \mathrm{VG}$ in $\mathrm{CH}_{3} \mathrm{CN}$ at $0{ }^{\circ} \mathrm{C}$; $[4 \mathrm{VG}]_{0} /[1]_{0} /\left[\mathrm{BF}_{3} \cdot \mathrm{OEt}_{2}\right]_{0} /\left[\mathrm{H}_{2} \mathrm{O}\right]_{0}=200 / 4.0 / 2.0 / 200 \mathrm{mM}$. For $M_{\mathrm{n}}$ and $M_{\mathrm{w}} / M_{\mathrm{n}}$ curves, the diagonal line indicates the calculated $M_{\mathrm{n}}$ assuming the formation of one polymer chain per 1 molecule.

This reaction system requires added water not for initiation but for polymerization control, whereas water usually acts as a chain-transfer agent or initiator (cationogen) in conventional 
cationic polymerization. Therefore, the effect of added water was also investigated for the cationic polymerization of $4 \mathrm{VG}$ in which the polymerization was performed at various water concentrations, i.e., from that equivalent to the monomer $(200 \mathrm{mM})$ to excess amounts ( $400 \mathrm{mM}$ and $1.0 \mathrm{M}$ ) (Figure 2). Although the addition of water clearly retarded the polymerization, the polymerization actually proceeded without prohibition even in the presence of a large excess of water. In addition, the MWD of the produced polymer became narrower as the amount of added water increased, whereas the $M_{\mathrm{n}}$ was not affected by the water concentration. This finding further indicates that the reaction of water with carbocations does not induce either chain-transfer or a termination reaction in this system but biases the equilibrium at the growing end between the alcohol and cationic species toward the dormant species.
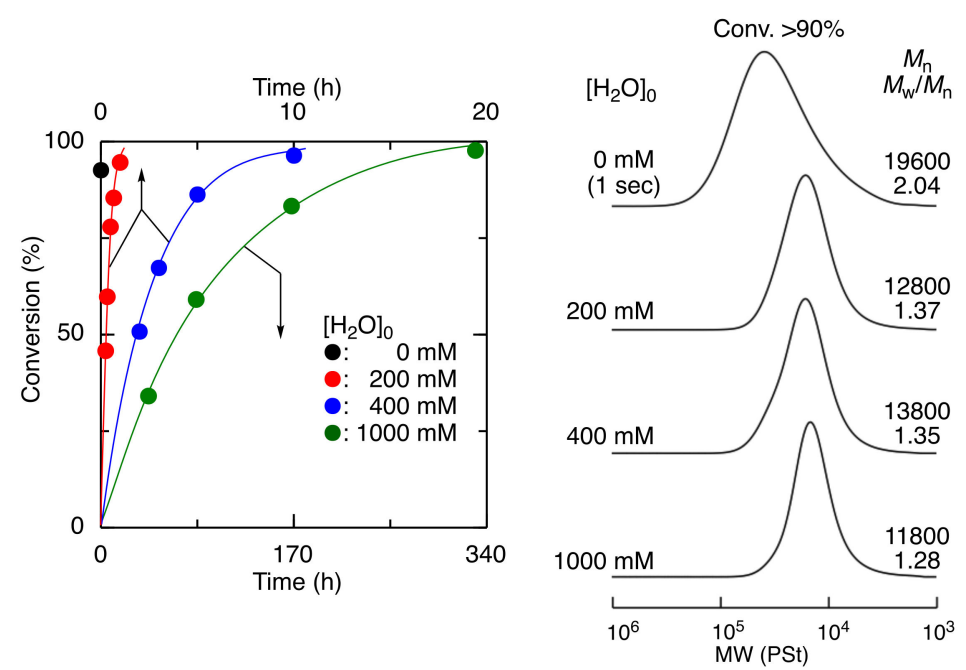

Figure 2. Effects of water on the controlled/living cationic polymerization of $4 \mathrm{VG}$ in $\mathrm{CH}_{3} \mathrm{CN}$ at $0{ }^{\circ} \mathrm{C}$; $[4 \mathrm{VG}]_{0} /[\mathrm{pMOS}-\mathrm{OH}]_{0} /\left[\mathrm{BF}_{3} \cdot \mathrm{OEt}_{2}\right]_{0} /\left[\mathrm{H}_{2} \mathrm{O}\right]_{0}=200 / 4.0 / 2.0 / 0,200,400$, or $1000 \mathrm{mM}$.

The polymer thus obtained from $4 \mathrm{VG}$ was analyzed by ${ }^{1} \mathrm{H}$ NMR and MALDI-TOF-MS. In the ${ }^{1} \mathrm{H}$ NMR spectrum (Figure 3A), a peak for the unprotected pendent hydroxyl group (e) was observed in addition to peaks derived from the main chain ( $a$ and $b)$, aromatic group $(c, d$, and $g$ ), and pendent methoxy group ( $f$ ), indicating that the $4 \mathrm{VG}$ polymer was produced by addition polymerization of the vinyl group. Furthermore, the molecular weight calculated from the integral ratios of peak $\alpha$ derived from initiator 1 and peak $f$ of the methoxy group $\left[M_{n}(N M R)=4700\right]$ agreed well with the calculated value obtained from the monomer conversion $\left[M_{n}(\mathrm{calcd})=4600\right]$. The MALDI-TOF-MS spectrum exhibited peaks separated by a molecular weight interval for 4VG in which the absolute molecular weight of each main peak was consistent with the polymers initiated with the methoxystyrene unit and almost terminated with the hydroxyl group (Figure 3B). These results also support that controlled/living polymers with a well-controlled terminal structure were obtained by aqueous-cationic polymerization of $4 \mathrm{VG}$ without any protecting groups. 
(A)

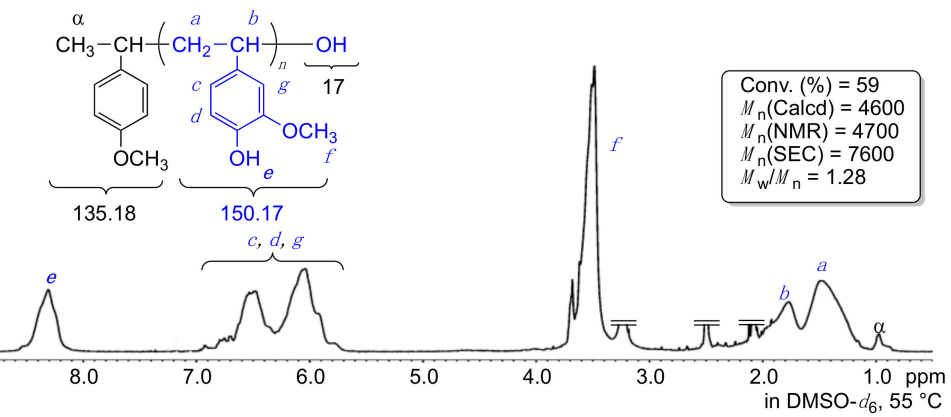

(B)
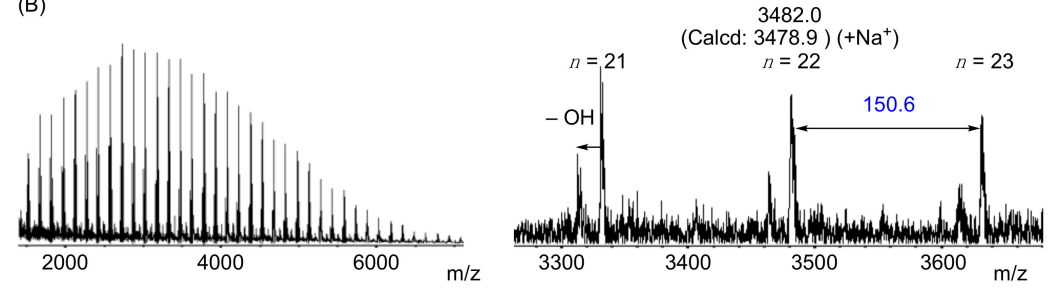

Figure 3. ${ }^{1} \mathrm{H}$ NMR (A) and MALDI-TOF-MS (B) spectrum of poly(4VG) obtained with $\mathbf{1} / \mathrm{BF}_{3} \cdot \mathrm{OEt}_{2}$ in $\mathrm{CH}_{3} \mathrm{CN}$ at $0{ }^{\circ} \mathrm{C}$ in the presence of water; $[4 \mathrm{VG}]_{0} /[1]_{0} /\left[\mathrm{BF}_{3} \cdot \mathrm{OEt}_{2}\right]_{0} /\left[\mathrm{H}_{2} \mathrm{O}\right]_{0}=200 / 4.0 / 2.0 / 1000 \mathrm{mM}$.

\subsection{Statistical and Block Copolymers of Vinylguaiacol with p-Methoxystyrene}

Based on the success of the direct-controlled/living cationic polymerization of $4 \mathrm{VG}$ in the aqueous system, we then studied random/statistical and block copolymerization of 4 VG. Herein, pMOS was employed as the comonomer, which is a cationically polymerizable and more hydrophobic styrene derived from petrochemicals, to prepare various types of 4VG-derived phenolic polystyrene copolymers [9].

The statistical random copolymerization of $4 \mathrm{VG}$ and pMOS was first conducted under the same conditions as for the homopolymerization except for the use of a mixture solvent of $\mathrm{CH}_{3} \mathrm{CN}$ and $\mathrm{CH}_{2} \mathrm{Cl}_{2}$ due to the solubility of the resulting polymer. The $1 / \mathrm{BF}_{3} \cdot \mathrm{OEt}_{2}$-based system was applied for the $4 \mathrm{VG} / \mathrm{pMOS}$ copolymerization at $0{ }^{\circ} \mathrm{C}$ in which the comonomer feed ratio was 1:1 (Figure 4). Both of the monomers were consumed quantitatively after $30 \mathrm{~h}$ and $4 \mathrm{VG}$ reacted slightly faster than pMOS probably due to higher number of electron-donating substituents on the aromatic ring of $4 \mathrm{VG}$. The SEC curves of the obtained copolymer also shifted to the higher molecular-weight region with relatively narrow MWDs $\left(M_{\mathrm{W}} / M_{\mathrm{n}} \sim 1.3\right)$. The formation of the controlled/living copolymer was also confirmed by ${ }^{1} \mathrm{H}$ NMR and MALDI-TOF MS (Figure S1). In particular, the MALDI-TOF-MS spectrum showed complicated peaks that represent the copolymers of $4 \mathrm{VG}$ and pMOS units distributed statistically, and the spectrum is free of the peaks of the corresponding homopolymers as in the case of pHS.
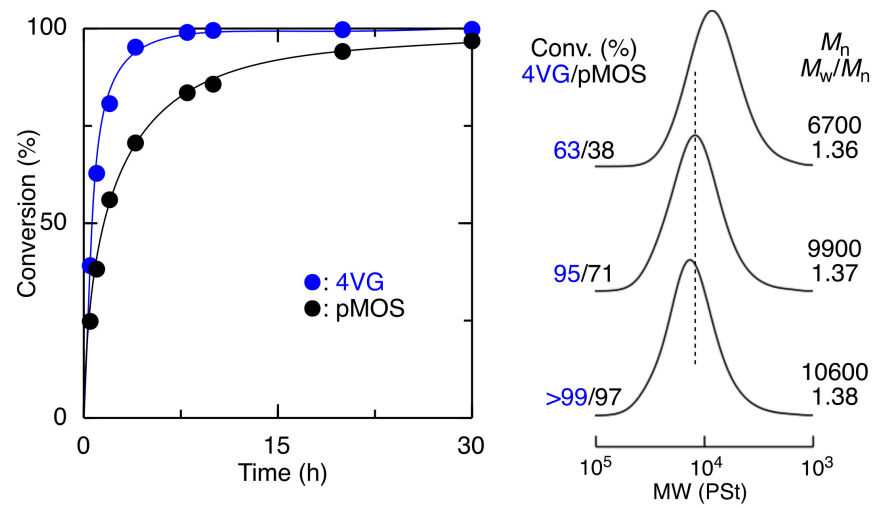

Figure 4. Statistical controlled/living cationic copolymerization of $4 \mathrm{VG}$ and $\mathrm{pMOS}$ with $1 / \mathrm{BF}_{3} \cdot \mathrm{OEt}_{2}$ in $\mathrm{CH}_{3} \mathrm{CN} / \mathrm{CH}_{2} \mathrm{Cl}_{2}(8 / 2)$ at $0{ }^{\circ} \mathrm{C} ;[4 \mathrm{VG}]_{0} /[\mathrm{pMOS}]_{0} /[1]_{0} /\left[\mathrm{BF}_{3} \cdot \mathrm{OEt}_{2}\right]_{0} /\left[\mathrm{H}_{2} \mathrm{O}\right]_{0}=100 / 100 / 4.0 / 2.0 / 200 \mathrm{mM}$. 
Furthermore, the sequential block copolymerization of $4 \mathrm{VG}$ and pMOS was also investigated using the $\mathrm{BF}_{3} \cdot \mathrm{OEt}_{2}$-based initiating system. The homopolymerization of $4 \mathrm{VG}$ was first performed with $\mathrm{R}-\mathrm{OH} / \mathrm{BF}_{3} \cdot \mathrm{OEt}_{2}$ in the presence of water at $0{ }^{\circ} \mathrm{C}$ in the mixed solvent of $\mathrm{CH}_{3} \mathrm{CN}$ and $\mathrm{CH}_{2} \mathrm{Cl}_{2}$. After polymerization of $4 \mathrm{VG}$ at ca. $90 \%$ conversion, $\mathrm{pMOS}$ as the second monomer was added to the reaction mixture. The second polymerization also proceeded well even after monomer addition. After the second polymerization, the SEC curves of the obtained copolymer also shifted maintaining relatively narrow MWDs, indicating the formation of the block copolymer (Figure 5). The block copolymer was also confirmed by ${ }^{1} \mathrm{H}$ NMR, where the incorporated ratio of the two monomers was in good agreement with the calculated values (Figure S2). Thus, the $\mathrm{BF}_{3} \cdot \mathrm{OEt}_{2}$-based aqueous-cationic system was also effective for controlling statistical/random and sequential block copolymerization of $4 \mathrm{VG}$ and pMOS to form a copolymer with hydrophilic and more hydrophobic segments.
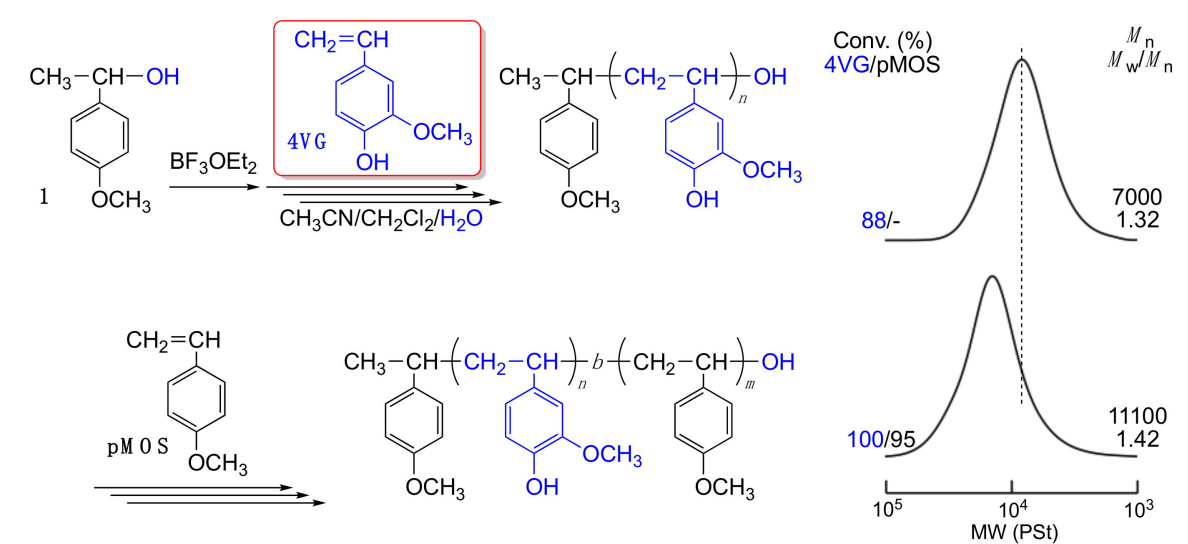

Figure 5. Block copolymerization of $4 \mathrm{VG}$ and pMOS with $1 / \mathrm{BF}_{3} \cdot \mathrm{OEt}_{2}$ in $\mathrm{CH}_{3} \mathrm{CN} / \mathrm{CH}_{2} \mathrm{Cl}_{2}(8 / 2)$ at $0{ }^{\circ} \mathrm{C} ;[4 \mathrm{VG}]_{0} /[\mathrm{pMOS}]_{\text {add }} /[1]_{0} /\left[\mathrm{BF}_{3} \cdot \mathrm{OEt}_{2}\right]_{0} /\left[\mathrm{H}_{2} \mathrm{O}\right]_{0}=100 / 100 / 4.0 / 2.0 / 200 \mathrm{mM}$.

\subsection{Properties of the Naturally-Derived Phenolic Polymers from Vinylguaiacol}

The thermal properties of the 4VG-based phenolic polymers were then evaluated by differential scanning calorimetry (DSC) and thermogravimetric analyses (TGA) (Figure 6). Figure 6A shows the DSC profiles of the homopolymer and copolymer of $4 \mathrm{VG}$. The glass transition temperature $\left(T_{\mathrm{g}}\right)$ of the $4 \mathrm{VG}$ homopolymer that has a molecular weight of approximately $10 \mathrm{~K}$ was $114{ }^{\circ} \mathrm{C}$, which is almost the same value as that of poly $(4 \mathrm{VG})$ obtained via radical polymerization of the protected-4VG and deprotection process. Upon copolymerization with $\mathrm{pMOS}$, the $T_{\mathrm{g}}$ values did not change considerably, where the $T_{\mathrm{g}}$ values for the statistical and block copolymers were 111 and $112{ }^{\circ} \mathrm{C}$, respectively. This is because the homopolymer of pMOS has almost the same $T_{\mathrm{g}}$ as poly(4VG). However, the copolymerization with nonfunctionalized pMOS slightly improved the thermal degradation temperature by TGA, as shown in Figure 6B. The thermal degradation of poly(4VG) began below $300{ }^{\circ} \mathrm{C}$, of which the $5 \%$ weight-loss temperature was $319^{\circ} \mathrm{C}$; however, those of the statistical and block copolymers were higher than $330^{\circ} \mathrm{C}$. 
(A)

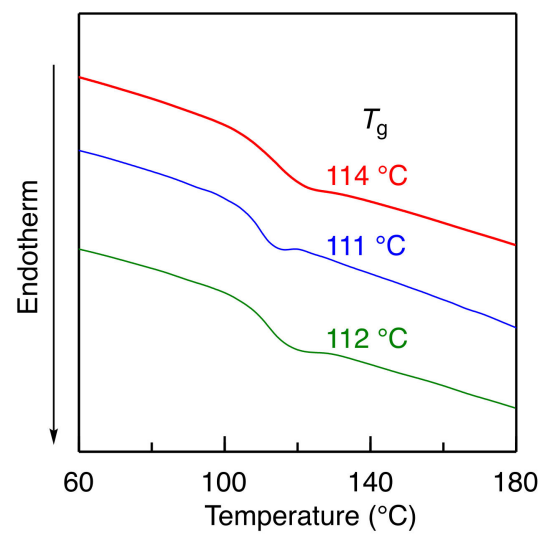

(B)

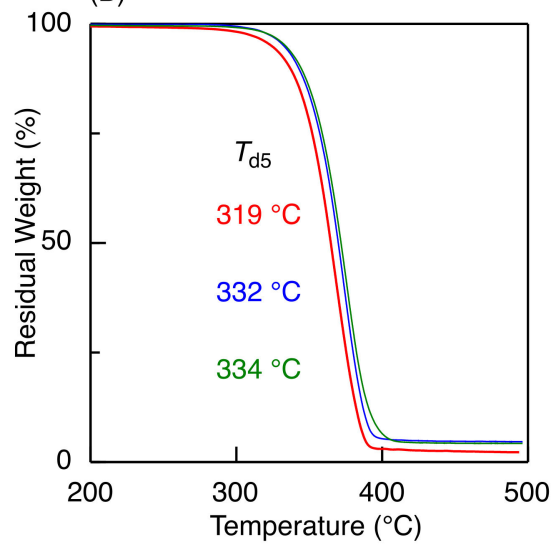

Figure 6. Differential scanning calorimetry (A) and thermogravimetric analysis (B) for poly $(4 \mathrm{VG})\left[M_{\mathrm{n}}\right.$ $\left.(\mathrm{SEC})=11,800, M_{\mathrm{w}} / M_{\mathrm{n}}=1.28\right]$ (red line), poly(4VG-stat-pMOS) $\left[M_{\mathrm{n}}(\mathrm{SEC})=10,600, M_{\mathrm{w}} / M_{\mathrm{n}}=1.38\right.$, $4 \mathrm{VG} / \mathrm{pMOS}=51 / 49]$ (blue line), and poly(4VG-block-pMOS) $\left[M_{\mathrm{n}}(\mathrm{SEC})=11,100, M_{\mathrm{w}} / M_{\mathrm{n}}=1.42\right.$, $4 \mathrm{VG} / \mathrm{pMOS}=51 / 49]$ (green line).

To check the amphiphilic nature of the homopolymer and copolymer of $4 \mathrm{VG}$, the solubilities of the phenolic copolymers were also evaluated in various solvents (Table 1). As previously reported, the amphiphilic poly $(4 \mathrm{VG})$ was easily soluble in methanol and aqueous sodium hydroxide $(1.0 \mathrm{M})$ solution as well as in acetone, THF, and ethyl acetate (EtOAc) but insoluble in toluene and chloroform. The solubility to an aqueous alkali solution is similar to poly(vinylphenol), which is widely used industrially as a photoresist material. Regarding the solubility of the copolymers with pMOS, they were more easily dissolved in chloroform but less soluble in methanol due to the introduction of more hydrophobic pMOS units. However, the random/statistical copolymer of $4 \mathrm{VG}$ and pMOS exhibited solubility in aqueous $\mathrm{NaOH}$ solution at a low concentration $(0.2 \mathrm{wt} \%)$. Thus, the amphiphilic nature of the 4VG-based phenolic polymer could be tuned via copolymerization with more hydrophobic pMOS.

Table 1. Solubility of various phenolic polystyrenes from $4 \mathrm{VG}^{a}$.

\begin{tabular}{|c|c|c|c|c|c|c|c|c|}
\hline Polymer $^{b}$ & $\mathrm{H}_{2} \mathrm{O}$ & $\mathrm{NaOH}$ aq & $\mathrm{CH}_{3} \mathrm{OH}$ & Acetone & THF & EtOAc & $\mathrm{CHCl}_{3}$ & Toluene \\
\hline Poly(4VG) & - & ++ & ++ & ++ & ++ & ++ & - & - \\
\hline Poly(pMOS) & - & - & - & ++ & ++ & ++ & ++ & ++ \\
\hline Poly(4VG-stat-pMOS) & - & + & - & ++ & ++ & ++ & ++ & - \\
\hline Poly(4VG-block-pMOS) & - & - & - & ++ & ++ & ++ & ++ & - \\
\hline
\end{tabular}

a "++": soluble (1 wt \%), "+": soluble $(0.2 \mathrm{wt} \%)$, "-": insoluble. ${ }^{b}$ The polymer samples are the same as in Figure 6.

\section{Conclusions}

In this study, we reported the water-based direct-controlled/living cationic polymerization of a plant-derived phenolic styrene, $4 \mathrm{VG}$, to develop novel naturally-derived amphiphilic polystyrenes. $4 \mathrm{VG}$ was successfully and quantitatively transformed into novel bio-based polymers by the $\mathrm{R}-\mathrm{OH} / \mathrm{BF}_{3} \cdot \mathrm{OEt}_{2}$ system without using any protective groups for the phenolic functional groups. In addition, 4VG could be copolymerized with a petroleum-derived styrene derivative, pMOS, in a controlled fashion to afford well-defined statistical and block copolymers with amphiphilic properties. We believe that this polymer can be expected not only to be used as a novel styrenic bio-based polymer but also as a material with amphiphilic nature for some applications, such as for photoresist and biomedical applications, due to its unique solubility and potential anti-oxidizing ability.

Supplementary Materials: The following are available online at http:/ /www.mdpi.com/2073-4360/10/12/1404/s1, Figure S1: ${ }^{1} \mathrm{H}$ NMR and MALDI-TOF-MS spectra of the statistical random copolymer of $4 \mathrm{VG}$ and pMOS obtained with $1 / \mathrm{BF}_{3} \cdot \mathrm{OEt}_{2}$, Figure S2: ${ }^{1} \mathrm{H}$ NMR spectra of poly(4VG) and $4 \mathrm{VG}-b$-pMOS block copolymer obtained with $1 / \mathrm{BF}_{3} \cdot \mathrm{OEt}_{2}$. 
Author Contributions: H.T., K.S., and M.K. conceived and designed the experiments; H.T. performed the experiments; H.T., K.S., and M.K. wrote the paper.

Funding: This research was funded by JSPS Research Fellowships for Young Scientists for H.T. (No. 18J15251).

Acknowledgments: This work was supported in part by the Program for Leading Graduate Schools "Integrative Graduate Education and Research Program in Green Natural Sciences".

Conflicts of Interest: The authors declare no conflicts of interest.

\section{References}

1. Müller, A.H.E.; Matyjaszewski, K. (Eds.) Controlled and Living Polymerizations: From Mechanisms to Applications; Wiley-VCH: Weinheim, Germany, 2010. ISBN 978-3-5273-2492-7.

2. Sawamoto, M. Modern cationic vinyl polymerization. Prog. Polym. Sci. 1991, 16, 111-172. [CrossRef]

3. Kennedy, J.P.; Iván, B. Designed Polymers by Carbocationic Macromolecular Engineering: Theory and Practice; Hanser: Munich, Germany, 1992. ISBN 0195209214.

4. Matyjaszewski, K. (Ed.) Cationic Polymerizations: Mechanisms, Synthesis, and Applications; Marcel Dekker: New York, NY, USA, 1996. ISBN 082479463X.

5. Puskas, J.E.; Kaszas, G. Living carbocationic polymerization of resonance-stabilized monomers. Prog. Polym. Sci. 2000, 25, 403-452. [CrossRef]

6. Goethals, E.J.; Du Prez, F. Carbocationic polymerizations. Prog. Polym. Sci. 2007, 32, 220-246. [CrossRef]

7. Aoshima, S.; Kanaoka, S. A Renaissance in Living Cationic Polymerization. Chem. Rev. 2009, 109, $5245-5287$. [CrossRef] [PubMed]

8. Satoh, K.; Kamigaito, M.; Sawamoto, M. Direct Living Cationic Polymerization of $p$-Hydroxystyrene with Boron Trifluoride Etherate in the Presence of Water. Macromolecules 2000, 33, 5405-5410. [CrossRef]

9. Satoh, K.; Kamigaito, M.; Sawamoto, M. Direct Synthesis of Amphiphilic Random and Block Copolymers of $p$-Hydroxystyrene and $p$-Methoxystyrene via Living Cationic Polymerization with $\mathrm{BF}_{3} \mathrm{OEt}_{2} / \mathrm{ROH}_{\text {Systems. }}$. Macromolecules 2000, 33, 5830-5835. [CrossRef]

10. Satoh, K.; Nakashima, J.; Kamigaito, M.; Sawamoto, M. Novel $\mathrm{BF}_{3} \mathrm{OEt}_{2} / \mathrm{R}-\mathrm{OH}$ Initiating System for Controlled Cationic Polymerization of Styrene in the Presence of Water. Macromolecules 2001, 34, 396-401. [CrossRef]

11. Kamigaito, M.; Nakashima, J.; Satoh, K.; Sawamoto, M. Controlled Cationic Polymerization of p-(Chloromethyl)styrene: $\mathrm{BF}_{3}$-Catalyzed Selective Activation of a $\mathrm{C}-\mathrm{O}$ Terminal from Alcohol. Macromolecules 2003, 36, 3540-3544. [CrossRef]

12. Satoh, K. Cationic Polymerization in Aqueous Media with Water-Tolerant Lewis Acids. Kobunshi Ronbunshu 2005, 62, 335-351. [CrossRef]

13. Kostjuk, S.V.; Radchenko, A.V.; Ganachaud, F. Controlled/Living Cationic Polymerization of p-Methoxystyrene in Solution and Aqueous Dispersion Using Tris(pentafluorophenyl)borane as a Lewis Acid: Acetonitrile Does the Job. Macromolecules 2007, 40, 482-490. [CrossRef]

14. Kostjuk, S.V.; Ganachaud, F. Cationic Polymerization of Vinyl Monomers in Aqueous Media: From Monofunctional Oligomers to Long-Lived Polymer Chains. Acc. Chem. Res. 2010, 43, 357-367. [CrossRef] [PubMed]

15. Meier, M.A.R.; Metzger, J.O.; Schubert, U.S. Plant oil renewable resources as green alternatives in polymer science. Chem. Soc. Rev. 2007, 36, 1788-1802. [CrossRef] [PubMed]

16. Gandini, A. Polymers from Renewable Resources: A Challenge for the Future of Macromolecular Materials. Macromolecules 2008, 41, 9491-9504. [CrossRef]

17. Kimura, Y. Molecular, Stractural, and Material Design of Bio-Based Polymers. Polym. J. 2009, 41, 797-807. [CrossRef]

18. Biermann, U.; Bornsheuer, U.; Meier, M.A.R.; Metzger, J.O.; Schäfer, H.J. Oils and Fats as Renewable Raw Materials in Chemistry. Angew. Chem. Int. Ed. 2011, 50, 3854-3871. [CrossRef] [PubMed]

19. Auvergne, R.; Caillol, S.; David, G.; Boutevin, B.; Pascault, J.-P. Biobased Themosetting Epoxy; Present and Future. Chem. Rev. 2014, 114, 1082-1115. [CrossRef] [PubMed]

20. Yao, K.; Tang, C. Controlled Polymerization of Next-Generation. Renewable Monomers and Beyond. Macromolecules 2013, 46, 1689-1712. [CrossRef] 
21. Miller, S.A. Sustainable Polymers: Opportunities for the Next Decade. ACS Macro Lett. 2013, 2, 550-554. [CrossRef]

22. Holmberg, A.L.; Reno, K.H.; Wool, R.P.; Epps, T.H., III. Biobased building blocks for the rational design of renewable block polymers. Soft Matter. 2014, 10, 7405-7424. [CrossRef] [PubMed]

23. Vilela, C.; Sousa, A.F.; Fonseca, A.C.; Serra, A.C.; Coelho, J.F.J.; Freire, C.S.R.; Silvestre, A.J.D. The quest for sustainable polyesters-Insights into the future. Polym. Chem. 2014, 5, 3119-3141. [CrossRef]

24. Iwata, T. Biodegradable and Bio-Based Polymers: Future Prospects of Eco-Friendly Plastics. Angew. Chem. Int. Ed. 2015, 54, 3210-3215. [CrossRef] [PubMed]

25. Zhu, Y.; Romain, C.; Williams, C.K. Sustainable polymers from renewable resources. Nature 2016, 540, 354-362. [CrossRef] [PubMed]

26. Froidevaux, V.; Negrell, C.; Caillol, S.; Pascault, J.-P.; Boutevin, B. Biobased Amines: From Synthesis to Polymers; Present and Future. Chem. Rev. 2016, 116, 14181-14224. [CrossRef] [PubMed]

27. Llevot, A.; Dannecker, P.-K.; von Czapiewski, M.; Over, L.C.; Söyer, Z.; Meier, M.A.R. Renewability is not Enough: Recent Advances in the Sustainable Synthesis of Biomass-Derived Monomers and Polymers. Chem. Eur. J. 2016, 22, 11510-11521. [CrossRef] [PubMed]

28. Thomsett, M.R.; Storr, T.E.; Monaghan, O.R.; Stockman, R.A.; Howdle, S.M. Progress in the sustainable polymers from terpenes and terpenoids. Green Mater. 2016, 4, 115-134. [CrossRef]

29. Llevot, A.; Grau, E.; Carlotti, S.; Grelier, S.; Cramail, H. From Lignin-derived Aromatic Compounds to Novel Biobased Polymers. Macromol. Rapid Commun. 2016, 37, 9-28. [CrossRef] [PubMed]

30. Schneiderman, D.K.; Hillmyer, M.A. There is a Great Future in Sustainable Polymers. Macromolecules 2017, 50, 3733-3749. [CrossRef]

31. Nguyen, H.T.H.; Qi, P.; Rostagno, M.; Feteha, A.; Miller, S.A. The quest for high glass transition temperature bioplastics. J. Mater. Chem. A 2018, 6, 9298-9331. [CrossRef]

32. Satoh, K.; Kamigaito, M. New Polymerization Methods for Biobased Polymers. In Bio-Based Polymers; Kimura, Y., Ed.; CMC: Tokyo, Japan, 2013; pp. 95-111. ISBN 978-4-7813-0271-3.

33. Kamigaito, M.; Satoh, K. Bio-based Hydrocarbon Polymers. In Encyclopedia of Polymeric Nanomaterials; Kobayashi, S., Müllen, K., Eds.; Springer: Heidelberg, Germany, 2015; Volume 1, pp. 109-118. ISBN 978-3-642-29649-9.

34. Kamigaito, M.; Satoh, K. Sustainable Vinyl Polymers via Controlled Polymerization of Terpenes. In Sustainable Polymers from Biomass; Tang, C., Ryu, C.Y., Eds.; Wiley-VCH: Weinheim, Germany, 2017; pp. 55-90. ISBN 978-3-5273-4016-3.

35. Satoh, K. Controlled/living polymerization of renewable vinyl monomers into bio-based polymers. Polym. J. 2015, 47, 527-536. [CrossRef]

36. Satoh, K.; Sugiyama, H.; Kamigaito, M. Biomass-derived heat-resistant hydrogenated alicyclic hydrocarbon polymers: Poly(terpenes) and their derivatives. Green Chem. 2006, 8, 878-882. [CrossRef]

37. Satoh, K.; Nakahara, A.; Mukunoki, K.; Sugiyama, H.; Saito, H.; Kamigaito, M. Sustainable cycloolefin polymer from pine tree oil for poly( $\beta$-pinene). Optoelectronics material and catalytic hydrogenation for high-molecular-weight hydrogenated: Living cationic polymerization of $\beta$-pinene. Polym. Chem. 2014, 5, 3222-3230. [CrossRef]

38. Miyaji, H.; Satoh, K.; Kamigaito, M. Bio-Based Polyketones by Selective Ring-Opening Radical Polymerization of $\alpha$-Pinene-Derived Pinocarvone. Angew. Chem. Int. Ed. 2016, 55, 1372-1376. [CrossRef] [PubMed]

39. Satoh, K.; Matsuda, M.; Nagai, K.; Kamigaito, M. AAB-Sequence Living Radical Chain Copolymerization of Naturally-Occurring Limonene with Maleimide: An End-to-End Sequence- Regulated Copolymer. J. Am. Chem. Soc. 2010, 132, 10003-10005. [CrossRef] [PubMed]

40. Matsuda, M.; Satoh, K.; Kamigaito, M. Periodically Functionalized and Grafted Copolymers via 1:2-Sequence-Regulated Radical Copolymerization of Naturally Occurring Functional Limonene and Maleimide Derivatives. Macromolecules 2013, 46, 5473-5482. [CrossRef]

41. Matsuda, M.; Satoh, K.; Kamigaito, M. Controlled Radical Copolymerization of Naturally-Occurring Terpenes with Acrylic Monomers in Fluorinated Alcohol. KGK Kaut. Gummi Kunstst. 2013, 66, 51-56.

42. Matsuda, M.; Satoh, K.; Kamigaito, M. 1:2-sequence-regulated radical copolymerization of naturally occurring terpenes with maleimide derivatives in fluorinated alcohol. J. Polym. Sci. Part A: Polym. Chem. 2013, 51, 1774-1785. [CrossRef] 
43. Ojika, M.; Satoh, K.; Kamigaito, M. BAB-random-C Monomer Sequence via Radical Terpolymerization of Limonene (A), Maleimide (B), and Methacrylate (C): Terpene Polymers with Randomly Distributed Periodic Sequences. Angew. Chem. Int. Ed. 2017, 56, 1789-1793. [CrossRef] [PubMed]

44. Satoh, K.; Saitoh, S.; Kamigaito, M. A Linear Lignin Analogue: Phenolic Alternating Copolymers from Naturally Occurring $\beta$-Methylstyrene via Aqueous-Controlled Cationic Copolymerization. J. Am. Chem. Soc. 2007, 129, 9586-9587. [CrossRef] [PubMed]

45. Nonoyama, Y.; Satoh, K.; Kamigaito, M. Renewable $\beta$-methylstyrenes for bio-based heat-resistant styrenic copolymers: Radical copolymerization enhanced by fluoroalcohol and controlled/living copolymerization by RAFT. Polym. Chem. 2014, 5, 3182-3189. [CrossRef]

46. Satoh, K.; Lee, D.-H.; Nagai, K.; Kamigaito, M. Precision Synthesis of Bio-Based Acrylic Thermoplastic Elastomer by RAFT Polymerization of Itaconic Acid Derivatives. Macromol. Rapid Commun. 2014, 35, 161-167. [CrossRef] [PubMed]

47. Takeshima, H.; Satoh, K.; Kamigaito, M. Bio-Based Functional Styrene Monomers Derived from Naturally Occurring Ferulic Acid for Poly(vinylcatechol) and Poly(vinylguaicol) via Controlled Radical Polymerization. Macromolecules 2017, 50, 4206-4216. [CrossRef]

48. Takeshima, H.; Satoh, K.; Kamigaito, M. Scalable Synthesis of Bio-Based Functional Styrene: Protected Vinyl Catechol from Caffeic Acid and Controlled Radical and Anionic Polymerizations Thereof. ACS. Sustain. Chem. Eng. 2018, 6, 13681-13686. [CrossRef]

49. Terao, Y.; Satoh, K.; Kamigaito, M. Controlled Radical Copolymerization of Cinnamic Derivatives as Renewable Vinyl Monomers with Both Acrylic and Styrenic Substituents: Reactivity, Regioselectivity, Properties, and Functions. Biomacromolecules. in press. [CrossRef] [PubMed]

50. Salvin, S.; Bourke, M.; Byrne, T. (Eds.) The New Crop Industries Handbook; Rural Industries Research and Development Corporation: Canberra, Autralia, 2004. ISBN 1-74151-610-2.

51. Baser, K.H.C.; Buchbauer, G. (Eds.) Handbook of Essential Oils, 2nd ed.; CRC Press: Boca Barton, FL, USA, 2016. ISBN 978-1-4665-9046-5.

52. Caisamigila, S.; Busquet, M.; Cardozo, P.W.; Castillejos, L.; Ferret, A. Essential Oils as Modifiers of Rumen Microbial Fermentation. J. Dairy Sci. 2007, 90, 2580-2595. [CrossRef]

53. Hatakeyama, H.; Hatakeyama, T. Lignin Structure, Properties, and Applications. Adv. Polym. Sci. 2009, 232, 1-63. [CrossRef]

54. Vanholme, R.; Morreel, K.; Ralph, J.; Boerjan, W. Lignin engineering. Curr. Opin. Plant Biol. 2008, 11, $278-285$. [CrossRef] [PubMed]

55. Gallone, B.; Steensels, J.; Prahl, T.; Soriaga, L.; Saels, L.; Herrera-Malaver, B.; Merlevede, A.; Roncoroni, M.; Voordeckers, K.; Miraglia, L.; et al. Domestication and Divergence of Saccharomyces cerevisiae Beer Yeasts. Cell 2016, 166, 1397-1410. [CrossRef] [PubMed]

56. Mishra, S.; Sachan, A.; Vidyarthi, A.S.; Sachan, S.G. Transformation of ferulic acid to 4-vinyl guaiacol as a major metabolite: A microbial approach. Rev. Environ. Sci. Bio/Technol. 2014, 13, 377-385. [CrossRef]

57. Briggs, D.E.; Boulton, C.A.; Brookes, P.A.; Stevens, R. Brewing: Science and Practice; CRC Press: Boca Raton, FL, USA, 2004; pp. 610-632. ISBN 978-1-8557-3490-6.

58. Mukai, N.; Masaki, K.; Fujii, T.; Iefuji, H. Single nucleotide polymorphisms of PAD1 and FDC1 show a positive relationship with ferulic acid decarboxylation ability among industrial yeasts used in alcoholic beverage production. Biosci. Bioeng. 2014, 118, 50-55. [CrossRef] [PubMed]

59. Cohen, L.A.; Jones, W.M. A Study of pH Dependence in the Decarboxylation of $p$-Hydroxycinnamic Acid. J. Am. Chem. Soc. 1960, 82, 1907-1911. [CrossRef]

60. Nomura, E.; Hosoda, A.; Mori, H.; Taniguchi, H. Rapid base-catalyzed decarboxylation and amide-forming reaction of substituted cinnamic acids via microwave heating. Green Chem. 2005, 7, 863-866. [CrossRef]

(C) 2018 by the authors. Licensee MDPI, Basel, Switzerland. This article is an open access article distributed under the terms and conditions of the Creative Commons Attribution (CC BY) license (http://creativecommons.org/licenses/by/4.0/). 